\title{
Rhodococcus luteus Is a Later Subjective Synonym of Rhodococcus fascians
}

\author{
STEFAN KLATTE*, KLAUS-DIETER JAHNKE, REINER MICHAEL KROPPENSTEDT, \\ FRED RAINEY, AND ERKO STACKEBRANDT
}

DSM-Deutsche Sammlung von Mikroorganismen und Zellkulturen GmbH, D-38124 Braunschweig, Germany

\begin{abstract}
The results of DNA-DNA hybridization studies and $16 \mathrm{~S}$ ribosomal DNA sequence comparisons and chemotaxonomic data clearly indicated that Rhodococcus luteus Nesterenko et al. 1982 (O. A. Nesterenko, T. M. Nogina, S. A. Kasumova, E. I. Kvasnikow, and S. G. Batrakov, Int. J. Syst. Bacteriol. 32:1-14, 1982) and Rhodococcus fascians (Tilford) Goodfellow 1984 (M. Goodfellow, Syst. Appl. Microbiol. 5:225-229, 1984) represent a single species. On the basis of priority $R$. luteus must be considered a later subjective synonym of R. fascians.
\end{abstract}

After the genus Rhodococcus Zopf 1891 was redefined by Goodfellow and Alderson in 1977 (8) and the genera Gordona (20) and Tsukamurella (3) were introduced, the genus Rhodococcus contained 13 validly described species (7), including two yellow-colored species, Rhodococcus luteus and the plantpathogenic organism Rhodococcus fascians (6). Since $R$. luteus and $R$. fascians had not been compared taxonomically previously, we performed this study to clarify the taxonomic relatedness of these organisms.

\section{MATERIALS AND METHODS}

Bacterial strains and cultivation. The following Rhodococcus strains were used in this study: $R$. coprophilus DSM 43339, DSM $43347^{\mathrm{T}}(\mathrm{T}=$ type strain), and DSM 43950; $R$. equi DSM $20307^{\mathrm{T}}$ and DSM 43349; $R$. erythropolis DSM 20655, DSM 43060, DSM 43066 ${ }^{\mathrm{T}}$, DSM 43135, DSM 43188, DSM 43200, DSM 43296, DSM 43297, DSM 43440, DSM 43441, DSM 43955, DSM 43957, and DSM 43958; $R$. fascians DSM $20669^{\mathrm{T}}$; $R$. globerulus DSM 43953 and DSM 43954 ${ }^{\mathrm{T}}$; $R$. luteus DSM $43673^{\mathrm{T}} ; R$. marinonascens DSM $43752^{\mathrm{T}} ;$ R. maris DSM $43672^{\mathrm{T}}$ and DSM 43275; $R$. rhodnii DSM 43336 ${ }^{\mathrm{T}}$, DSM 43337, and DSM 43959; $R$. rhodochrous DSM 43198, DSM 43202, DSM 43234, DSM 43241 ${ }^{\mathrm{T}}$, DSM 43269, DSM 43273, DSM 43334, DSM 43564, DSM 43565, DSM 43956, DSM 43961, DSM 43963, and DSM 43986; and $R$. ruber DSM 43001, DSM 43002, DSM 43008, DSM 43232, DSM 43278, DSM 43302, DSM 43335, DSM 43338 ${ }^{\mathrm{T}}$, DSM 43561, DSM 43562, DSM 43563, DSM 43945, and DSM 43952. For fatty acid and mycolic acid pattern analyses and $16 \mathrm{~S}$ ribosomal DNA sequencing, all strains were grown on TSB agar (3\% [wt/vol] Trypticase soy broth [BBL], $1.5 \%$ [wt/vol] Bacto-Agar [Difco]) for 4 days at $28^{\circ} \mathrm{C}$. $R$. marinonascens was grown on seawater agar $(10.0 \mathrm{~g}$ of beef extract, $10.0 \mathrm{~g}$ of peptone, $750 \mathrm{ml}$ of seawater, $250 \mathrm{ml}$ of tap water, $20.0 \mathrm{~g}$ of Bacto-Agar [Difco]) at $20^{\circ} \mathrm{C}$ for 14 days. For biochemical examination all strains were cultivated on GYM agar $(0.4 \%$ [wt/vol] D-glucose, $0.4 \%$ [wt/vol] yeast extract, $1 \%$ [wt/vol] malt extract, $1.2 \%$ [wt/vol] agar no. 1 [Oxoid]) for 3 days at $28^{\circ} \mathrm{C}$. For the DNA hybridization experiments strains were grown in Trypticase soy broth (BBL) for 4 days at $28^{\circ} \mathrm{C}$ on a rotary shaker, checked for purity, killed

${ }^{*}$ Corresponding author. Mailing address: DSM-Deutsche Sammlung von Mikroorganismen und Zellkulturen $\mathrm{GmbH}$, Mascheroder Weg 1B, D-38124 Braunschweig, Germany. Phone: 49-531-2616-241. Fax: 49-531-2616-418. by adding $1 \%$ (vol/vol) formaldehyde, harvested by centrifugation, and washed twice with distilled water.

Phenotypic characterization. For each strain carbon source utilization tests and qualitative enzyme tests in which chromogenic substrates were used were performed in standard microtitration plates (F-form; Greiner, Nürtingen, Germany) as described by Kämpfer et al. (13), with the following modifications: the carbon source utilization test medium used contained yeast-nitrogen base (Difco), yeast extract $(0.02$ $\mathrm{g} /$ liter $), \mathrm{K}_{2} \mathrm{HPO}_{4}$ (1.74 g/liter), and $\mathrm{KH}_{2} \mathrm{PO}_{4}(0.36 \mathrm{~g} /$ liter $)$; and the enzyme test medium used contained $0.05 \mathrm{M}$ Tris- $\mathrm{HCl}$ buffer, $0.05 \%$ (wt/vol) Casamino Acids (Difco), and $0.05 \%$ (wt/vol) yeast extract (Difco). The test panels were inoculated with a standardized bacterial suspension ( 0.5 to $1.0 \mathrm{McF}$ arland unit) in $0.9 \%$ (wt/vol) $\mathrm{NaCl}$ and were incubated for $24 \mathrm{~h}$ at $28^{\circ} \mathrm{C}$. After $50 \mu \mathrm{l}$ of a filter-sterilized indicator solution containing $4 \mathrm{mM}$ phenazine methosulfate (Sigma) and $4 \mathrm{mM}$ tetrazolium-[3-(4,5-dimethylthiazol-2-yl)-2,5-diphenyltetrazoliumbromide]) (MTT) (Sigma) had been added to the auxonographic test and control wells, incubation was continued for 24 $\mathrm{h}$ in the dark. Formation of the deep-blue compound formazan was taken as an indication that a carbon source was utilized (14). The auxonographic test results were determined photometrically with a Multiscan model MCC340 MKII photometer (Flow Laboratories, Meckenheim, Germany). Metabolization of a carbon source was considered positive if $E_{540}$ (test substrate) $-E_{540}$ (control) $>0.129$. The results of the enzyme tests were evaluated visually.

Lipid analysis. Fatty acid methyl esters were prepared from wet cells (40 to $70 \mathrm{mg}$ ) as described previously (16) and were identified with a model 5898A Microbial Identification System (Microbial ID, Newark, Del.). Trimethylsilylated derivatives of mycolic acids were analyzed by high-temperature gas chromatography and coupled gas chromatography-mass spectrometry.

DNA isolation and characterization. DNA was isolated by chromatography on hydroxyapatite by the procedure of Cashion et al. (1). DNA-DNA hybridization was carried out as described by De Ley et al. (4), with the modifications described by Huss et al. (11) and Escara and Hutton (5), using a Gilford System model 2600 spectrophotometer equipped with a Gilford model 2527-R thermoprogrammer and plotter. Renaturation rates were computed with the TRANSFER.BAS program (12).

16S ribosomal DNA sequencing. Extraction of genomic DNA and amplification of 16S ribosomal DNA were carried out as described previously (18). PCR products were se- 
TABLE 1. Physiological properties of several rhodococci, including R. fascians DSM 20669 ${ }^{\mathrm{T}}$ and R. luteus DSM $43673^{\mathrm{T}}$

\begin{tabular}{|c|c|c|c|c|c|c|c|c|c|c|}
\hline \multirow[b]{2}{*}{ Characteristic } & \multicolumn{10}{|c|}{ Reaction of $f^{a}$ : } \\
\hline & $\begin{array}{l}\text { R. coprophilus } \\
(n=3)^{b}\end{array}$ & $\begin{array}{l}\text { R. equi } \\
(n=2)\end{array}$ & $\begin{array}{l}\text { R. enthropolis } \\
(n=13)\end{array}$ & $\begin{array}{l}\text { R. fascians } \\
(n=1)\end{array}$ & $\begin{array}{l}\text { R. luteus } \\
(n=1)\end{array}$ & $\begin{array}{l}\text { R. globerulus } \\
\quad(n=2)\end{array}$ & $\begin{array}{l}\text { R. maris } \\
(n=2)\end{array}$ & $\begin{array}{l}\text { R. rhodnii } \\
(n=3)\end{array}$ & $\begin{array}{l}\text { R. rhodochrous } \\
(n=13)\end{array}$ & $\begin{array}{l}\text { R. ruber } \\
(n=13)\end{array}$ \\
\hline \multicolumn{11}{|l|}{ Utilization of } \\
\hline D-Galactose & 0 & 100 & 85 & + & + & 0 & 0 & 100 & 85 & 38 \\
\hline L-Rhamnose & 0 & 50 & 0 & - & - & 0 & 0 & 0 & 23 & 23 \\
\hline D-Ribose & 0 & 100 & 92 & + & + & 0 & 0 & 33 & 15 & 8 \\
\hline D-Sucrose & 0 & 0 & 92 & + & + & 50 & 0 & 0 & 31 & 46 \\
\hline D-Turnanose & 0 & 0 & 0 & - & - & 0 & 0 & 0 & 0 & 0 \\
\hline D-Arabitol & 0 & 0 & 92 & + & + & 100 & 0 & 100 & 100 & 100 \\
\hline$i$-Inositol & 0 & 0 & 100 & - & - & 0 & 0 & 0 & 0 & 15 \\
\hline $\begin{array}{l}N \text {-acetyl-D- } \\
\text { glucosamine }\end{array}$ & 0 & 0 & 77 & + & - & 0 & 0 & 0 & 0 & 8 \\
\hline Glucarate & 0 & 50 & 31 & - & - & 0 & 0 & 0 & 46 & 0 \\
\hline Gluconate & 33 & 0 & 100 & + & + & 100 & 0 & 100 & 8 & 15 \\
\hline $\begin{array}{l}\text { D-Glucosaminic } \\
\text { acid }\end{array}$ & 0 & 50 & 8 & + & + & 0 & 0 & 0 & 8 & 8 \\
\hline Caprate & 0 & 100 & 92 & + & + & 100 & 0 & 67 & 69 & 54 \\
\hline Citrate & 0 & 0 & 100 & + & - & 100 & 0 & 0 & 62 & 85 \\
\hline 4-Aminobutyrate & 0 & 0 & 54 & - & - & 50 & 50 & 0 & 0 & 62 \\
\hline 2-Hydroxyvalerate & 0 & 100 & 85 & + & + & 0 & 0 & 33 & 8 & 8 \\
\hline 2-Oxoglutarate & 33 & 50 & 69 & + & + & 0 & 50 & 33 & 46 & 54 \\
\hline Pimelate & 0 & 0 & 38 & - & - & 100 & 0 & 0 & 23 & 31 \\
\hline Succinate & 0 & 100 & 100 & + & - & 100 & 0 & 100 & 62 & 69 \\
\hline Benzoate & 67 & 0 & 31 & - & - & 50 & 0 & 0 & 46 & 69 \\
\hline 3-Hydroxybenzoate & 100 & 50 & 0 & - & - & 50 & 0 & 0 & 54 & 92 \\
\hline 4-Hydroxybenzoate & 0 & 100 & 69 & - & - & 50 & 0 & 0 & 62 & 92 \\
\hline Phenylacetate & 0 & 0 & 62 & - & - & 0 & 0 & 0 & 38 & 46 \\
\hline Quinate & 0 & 0 & 100 & + & - & 100 & 0 & 0 & 100 & 100 \\
\hline L-Alanine & 0 & 0 & 100 & + & - & 0 & 0 & 0 & 15 & 15 \\
\hline L-Aspartate & 0 & 50 & 0 & - & - & 0 & 0 & 0 & 0 & 0 \\
\hline L-Leucine & 0 & 50 & 85 & - & + & 100 & 0 & 33 & 31 & 62 \\
\hline L-Proline & 0 & 0 & 38 & - & + & 0 & 0 & 0 & 0 & 8 \\
\hline L-Serine & 0 & 0 & 46 & - & - & 0 & 0 & 0 & 0 & 8 \\
\hline L-Valine & 0 & 0 & 100 & - & + & 100 & 0 & 0 & 69 & 31 \\
\hline Putrescine & 0 & 0 & 100 & - & - & 100 & 0 & 0 & 8 & 100 \\
\hline Tyramine & 0 & 0 & 15 & - & + & 0 & 0 & 0 & 48 & 23 \\
\hline & 0 & 100 & 85 & - & - & 0 & 0 & 100 & 18 & 77 \\
\hline \multicolumn{11}{|l|}{ Hydrolysis of ${ }^{d}$ : } \\
\hline CXY & 0 & 0 & 100 & - & - & 100 & 0 & 0 & 85 & 8 \\
\hline $\mathrm{CCH}$ & 0 & 100 & 100 & - & - & 100 & 0 & 0 & 8 & 69 \\
\hline CDP & 0 & 100 & 100 & - & - & 100 & 0 & 0 & 77 & 69 \\
\hline
\end{tabular}

The values are the percentages of positive strains. + , positive; - , negative.

${ }^{b} n$ is the number of strains tested.

${ }^{c}$ Utilization of carbon sources was detected by MTT reduction.

${ }^{d}$ Enzymatic activity was detected by hydrolysis of chromogenic substrates. Abbreviations: CXY, $p$-nitrophenyl- $\beta$-D-xyloside; CCH, $p$-nitrophenyl-phosphoryl-choline; CDP, 2-deoxythymidine-5'-p-nitrophenyl phosphate.

TABLE 2. Whole-cell fatty acid compositions of several rhodococci, including $R$. fascians DSM $20669^{\mathrm{T}}$ and $R$. luteus DSM $43673^{\mathrm{T}}$

\begin{tabular}{|c|c|c|c|c|c|c|c|c|c|c|c|c|c|c|}
\hline \multirow[b]{2}{*}{ Species } & \multirow{2}{*}{$\begin{array}{l}\text { No. of } \\
\text { strains }\end{array}$} & \multicolumn{13}{|c|}{$\%$ of ${ }^{a}:$} \\
\hline & & $C_{14: 0}$ & $C_{15: 0}$ & $C_{16: 1 \omega 7}$ & $C_{16: 1 \omega \sigma}$ & $C_{16: 0}$ & $\begin{array}{c}10-\mathrm{Me} \\
\mathrm{C}_{16: 0}\end{array}$ & $C_{17: 1 \omega 8}$ & $\mathrm{C}_{17: 0}$ & $\begin{array}{c}10-\mathrm{Me} \\
\mathrm{C}_{17: 0}\end{array}$ & $\mathrm{C}_{18: 1 \omega 9}$ & $C_{18: 0}$ & $\begin{array}{l}10-\mathrm{Me} \\
\mathrm{C}_{18: 0^{b}}\end{array}$ & $C_{19: 1 \omega 11}$ \\
\hline R. coprophilus & 3 & 1 & 3 & 9 & 14 & 19 & 6 & 4 & 2 & 3 & 10 & 1 & 22 & 1 \\
\hline R. equi & 2 & 3 & 1 & 1 & 12 & 32 & 3 & & 2 & 1 & 5 & 1 & 34 & 1 \\
\hline R. erythropolis & 13 & 6 & 5 & 2 & 15 & 25 & 3 & 3 & 2 & 4 & 10 & & 18 & 3 \\
\hline R. fascians ${ }^{c}$ & 1 & 5 & 20 & & 10 & 9 & & 11 & 2 & 4 & 15 & & 8 & 12 \\
\hline R. luteus ${ }^{c}$ & 1 & 5 & 17 & & 13 & 14 & & 7 & 2 & 4 & 15 & & 11 & 8 \\
\hline R. globerulus & 2 & 4 & 2 & 1 & 14 & 30 & 1 & 2 & 1 & 2 & 12 & 2 & 23 & \\
\hline R. marinonascens ${ }^{c}$ & 1 & 2 & 23 & & 3 & 7 & & 22 & 20 & 2 & 7 & 1 & 1 & \\
\hline R. maris & 2 & & 6 & 5 & 8 & 22 & 1 & 15 & 6 & 4 & 18 & & 12 & 1 \\
\hline R. rhodnii & 3 & & 4 & 1 & 14 & 29 & & 5 & 3 & 4 & 18 & 1 & 18 & 1 \\
\hline R. rhodochrous & 13 & 2 & 1 & 6 & 18 & 29 & 7 & 1 & 1 & 2 & 8 & 1 & 22 & \\
\hline R. ruber & 13 & 2 & 4 & 2 & 20 & 25 & 2 & 4 & 3 & 3 & 16 & 1 & 18 & 1 \\
\hline
\end{tabular}

${ }^{a}$ Means of the values of major components obtained for type and reference strains.

${ }^{b}$ Tuberculostearic acid.

${ }^{c}$ Data for the type strain. 
TABLE 3. Mycolic acid compositions of several rhodococci, including $R$. fascians DSM $20669^{\mathrm{T}}$ and $R$. luteus DSM $43673^{\mathrm{T}}$

\begin{tabular}{|c|c|c|c|c|c|c|c|c|c|c|c|c|c|c|c|c|c|c|c|c|c|c|c|}
\hline \multirow{2}{*}{ Species } & \multirow{2}{*}{$\begin{array}{l}\text { No. of } \\
\text { strains }\end{array}$} & \multicolumn{22}{|c|}{$\%$ of mycolic acids with the following no. of carbon atoms ${ }^{a}$ : } \\
\hline & & 30 & 31 & 32 & 33 & 34 & 35 & 36 & 37 & 38 & 39 & 40 & 41 & 42 & 43 & 44 & 45 & 46 & 47 & 48 & 49 & 50 & 51 \\
\hline R. coprophilus & 3 & & & & & & & 2 & & 8 & 4 & 20 & 10 & 24 & 7 & 12 & 8 & & 1 & & & & \\
\hline R. equi & 2 & 5 & & 25 & 6 & 31 & 10 & 16 & & & & & & & & & & & & & & & \\
\hline R. erythropolis & 13 & 2 & & 5 & 3 & 10 & 5 & 17 & 7 & 16 & 5 & 10 & 4 & 5 & & 2 & & & & & & & \\
\hline R. fascians $b$ & 1 & & & & & & & & & & & & & & & 7 & 6 & 17 & 9 & 23 & 14 & 14 & 9 \\
\hline R. luteus ${ }^{b}$ & 1 & & & & & & & & & & & & & & & 4 & 5 & 14 & 11 & 25 & 15 & 19 & 7 \\
\hline R. globerulus & 2 & 7 & 2 & 17 & 3 & 24 & 4 & 19 & 2 & 11 & 2 & 6 & & 2 & & & & & & & & & \\
\hline R. marinonascens ${ }^{b}$ & 1 & & & & & 2 & 2 & 7 & 4 & 7 & 5 & 6 & 5 & 2 & 2 & 5 & 5 & 13 & 5 & 8 & 14 & 6 & \\
\hline R. maris & 2 & & & & & 14 & 21 & 35 & 16 & 9 & & & & & & & & & & & & & \\
\hline R. rhodnii & 3 & & & & & & & & & & & & & 4 & 1 & 5 & 4 & 14 & 9 & 20 & 11 & 16 & 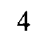 \\
\hline R. rhodochrous & 13 & & & & & & & & & 11 & & 16 & & 25 & 6 & 21 & 2 & 13 & & & & & \\
\hline R. ruber & 13 & & & & & & & & & & & 2 & 2 & 9 & 7 & 19 & 9 & 24 & 6 & 15 & & & \\
\hline
\end{tabular}

${ }^{a}$ Means of the values of major components obtained for type and reference strains.

${ }^{b}$ Data for the type strain.

quenced directly by using a Taq DyeDeoxy Terminator Cycle sequencing kit (Applied Biosystems) according to the manufacturer's protocol. The sequence reaction mixtures were electrophoresed with an Applied Biosystems model 373A DNA sequencer.

Nucleotide sequence accession numbers. The sequences determined in this study have been deposited in the EMBL database under accession numbers X79186 ( $R$. fascians DSM $20669^{\mathrm{T}}$ ) and X79187 (R. luteus DSM 43673 ${ }^{\mathrm{T}}$ ).

\section{RESULTS AND DISCUSSION}

$R$. luteus and $R$. fascians were validly described in 1982 and 1984 , respectively. The natural relatedness of these two species has not been investigated in detail previously. Neither in numerical phenetic investigations $(9,10)$ nor in DNA-DNA hybridization studies (22) have the type strains of these taxa been subjected to direct comparison, nor have the chemotaxonomic properties of these organisms been examined in detail previously. During a recent study of mycolic acid-containing actinomycetes, both the fatty acid and the mycolic acid compositions of the type strains of $R$. luteus and $R$. fascians were found to be quite similar, as well as significantly different from the fatty acid and mycolic acid compositions of Rhodococcus species. Furthermore, differences in the physiological capabilities of the two type strains were detected (Table 1) which, with the exception of utilization of quinate, may be considered strain-specific variations, as indicated by the data obtained with strains belonging to other species. The fatty acids were mainly straight-chain, saturated and unsaturated fatty acids, and tuberculostearic acid was a diagnostic compound; diagnostic amounts of $C_{15: 0}, C_{19: 1 \omega 11}$, and $C_{16: 0}$ were present (Table 2).

TABLE 4. Mycolic acid compositions of $R$. fascians DSM $20669^{\mathrm{T}}$ and $R$. luteus DSM $43673^{\mathrm{T}}$

\begin{tabular}{|c|c|c|c|c|c|c|c|c|c|c|}
\hline \multirow[b]{2}{*}{ Strain } & \multicolumn{10}{|c|}{ Peak areas $(\%)$ of the following mycolic acids: } \\
\hline & $44: 2^{a}$ & $45: 2$ & $46: 2$ & $47: 2$ & $48: 3$ & $48: 2$ & $49: 3$ & $49: 2$ & $\begin{array}{c}50: 3 \\
\text { and } \\
50: 2^{b}\end{array}$ & $\begin{array}{c}51: 3 \\
\text { and } \\
51: 2^{b}\end{array}$ \\
\hline $\begin{array}{l}\text { R. fascians DSM } \\
20669^{\mathrm{T}}\end{array}$ & 7 & 6 & 17 & 9 & 7 & 16 & 7 & 7 & 14 & 9 \\
\hline $\begin{array}{l}\text { R. luteus DSM } \\
43673^{\mathrm{T}}\end{array}$ & 4 & 5 & 14 & 11 & 4 & 21 & 5 & 10 & 19 & 7 \\
\hline
\end{tabular}

The molecular species of the mycolic acids of these organisms contained from 44 to 51 carbon atoms, with up to two double bonds per molecule (Table 3), corresponding to the composition described by Collins et al. (2) (Table 4). Because of the findings described above, our chemotaxonomic analyses were followed by a spectroscopic DNA-DNA hybridization analysis of the two type strains. The resulting binding value, $79 \% \pm 1 \%$ (mean \pm standard deviation of three replicates), indicated clearly that genomically the two type strains belong to the same species, assuming that species boundaries occur at DNA similarity values of approximately $70 \%$ (21). In addition, a comparison of the $16 \mathrm{~S}$ ribosomal DNA sequences revealed that the level of sequence similarity between $R$. luteus and $R$. fascians was $99.3 \%$. In conclusion, chemotaxonomic and genetic data provided clear evidence against the current taxonomic status of $R$. luteus and $R$. fascians as two distinct species, while the physiological variability observed $(9,10)$ might contribute to differences in phytopathogenicity (the phytopathogenicity of $R$. luteus has not been determined). The two type strains should be considered members of a single species. If taxa of equal rank are unified, the oldest legitimate name or epithet should be retained for the new combination according to Rule 42 of the International Code of Nomenclature of Bacteria (15). In this case, only the epithet fascians was included on the Approved Lists of Bacterial Names (19), as "Corynebacterium fascians"; therefore, this epithet has nomenclatural priority over the epithet luteus, which was validly published in 1982 (17). Consequently, R. luteus should be considered a later subjective synonym of $R$. fascians.

\section{REFERENCES}

1. Cashion, P., M. A. Holder-Franklin, J. McCully, and M. Franklin. 1977. A rapid method for the base ratio determination of bacterial DNA. Anal. Biochem. 81:461-466.

2. Collins, M. D., M. Goodfellow, and D. E. Minnikin. 1982. A survey of the structures of mycolic acids in Corynebacterium and related taxa. J. Gen. Microbiol. 128:129-149.

3. Collins, M. D., J. Smida, M. Dorsch, and E. Stackebrandt. 1988 Tsukamurella gen. nov. harboring Corynebacterium paurometabulum and Rhodococcus aurantiacus. Int. J. Syst. Bacteriol. 38:385391.

4. De Ley, J., H. Cattoir, and A. Reynaerts. 1970. The quantitative measurement of DNA hybridisation from renaturation rates. Eur. J. Biochem. 12:133-142.

5. Escara, J. F., and J. R. Hutton. 1980. Thermal stability and renaturation of DNA in dimethylsulphoxide solutions: acceleration of renaturation rate. Biopolymers 19:1315-1327.

6. Goodfellow, M. 1984. Reclassification of Corynebacterium fascians (Tilford) Dowson in the genus Rhodococcus, as Rhodococcus 
fascians comb. nov. Syst. Appl. Microbiol. 5:225-229.

7. Goodfellow, M. 1992. The family Nocardiaceae, p. 1188-1213. In A. Balows, H. G. Trüper, M. Dworkin, W. Harder, and K. H. Schleifer (ed.), The procaryotes, 2nd ed., Springer-Verlag, New York.

8. Goodfellow, M., and G. Alderson. 1977. The actinomycete genus Rhodococcus: a home for the 'rhodochrous' complex. J. Gen. Microbiol. 100:99-102.

9. Goodfellow, M., E. G. Thomas, and A. L. James. 1987. Characterisation of rhodococci using peptide hydrolase substrates based on 7-amino-4-methyl-coumarin. FEMS Microbiol. Lett. 44:349-355.

10. Goodfellow, M., E. G. Thomas, A. C. Ward, and A. L. James. 1990. Classification and identification of rhodococci. Zentralbl. Bakteriol. 274:299-315.

11. Huss, V. A. R., H. Festl, and K. H. Schleifer. 1983. Studies on the spectrophotometric determination of DNA hybridization from renaturation rates. J. Syst. Appl. Microbiol. 4:184-192.

12. Jahnke, K.-D. 1992. BASIC computer program for evaluation of spectroscopic DNA renaturation data from GILFORD SYSTEM 2600 spectrophotometer on a PC/XT/AT type personal computer. J. Microbiol. Methods 15:61-73.

13. Kämpfer, P., W. Dott, and R. M. Kroppenstedt. 1990. Numerical classification and identification of some nocardioform bacteria. $\mathbf{J}$. Gen. Appl. Microbiol. 36:309-391.

14. Kirchof, H., C. Maas, M. Runge, B. Franz, R. Schmidt, H. Quentmeier, and P. F. Mühlhardt. 1992. Tetrazolium-[3-(4,5dimethylthiazol-2-yl)-2,5-diphenyltetrazolium bromide] reduction by mycoplasmas. Int. J. Syst. Bacteriol. 42:506-508.

15. Lapage, S. P., P. H. A. Sneath, E. F. Lessel, V. B. D. Skerman, H. P. R. Seeliger, and W. A. Clark (ed.). 1992. International code of nomenclature of bacteria. 1990 Revision. American Society for Microbiology, Washington, D.C.

16. Miller, L., and T. Berger. 1985. Bacterial identification by gas chromatography of whole cell fatty acids. Gas chromatography applications note 228-41. Hewlett-Packard Co., Palo Alto, Calif.

17. Nesterenko, O. A., T. M. Nogina, S. A. Kasumova, E. I. Kvasnikow, and S. G. Batrakov. 1982. Rhodococcus luteus nom. nov. and Rhodococcus maris nom. nov. Int. J. Syst. Bacteriol. 32:1-14.

18. Rainey, F. A., M. Dorsch, H. W. Morgan, and E. Stackebrandt. 1992. 16S rDNA analysis of Spirochaeta thermophila: position and implications for the systematics of the order Spirochaetales. Syst. Appl. Microbiol. 16:224-226.

19. Skerman, V. B. D., V. McGowan, and P. H. A. Sneath (ed.). 1980. Approved lists of bacterial names. Int. J. Syst. Bacteriol. 30:225420 .

20. Stackebrandt, E., J. Smida, and M. D. Collins. 1988. Evidence of phylogenetic heterogeneity within the genus Rhodococcus: revival of the genus Gordona (Tsukamura). J. Gen. Appl. Microbiol. 34:341-348.

21. Wayne, L. G., D. J. Brenner, R. R. Colwell, P. A. D. Grimont, O. Kandler, M. I. Krichevsky, L. H. Moore, W. E. C. Moore, R. G. E. Murray, E. Stackebrandt, M. P. Starr, and H. G. Trüper. 1987. Report of the Ad Hoc Committee on Reconciliation of Approaches to Bacterial Systematics. Int. J. Syst. Bacteriol. 37:463464.

22. Zakrzewska-Czerwinska, J., M. Mordarski, and M. Goodfellow. 1988. DNA base composition and homology values in the classification of some Rhodococcus species. J. Gen. Microbiol. 134: 2807-2813. 